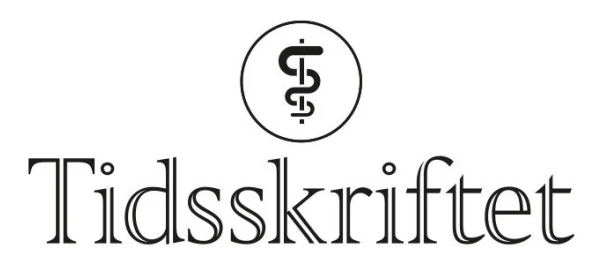

DEN NORSKE LEGEFORENING

\title{
Utvikling av ny behandling for multippel sklerose
}

\author{
OVERSIKTSARTIKKEL
}

\section{TRYGVE HOLMØY}

Email: trygve.holmoy@rr-research.no

Oslo universitetssykehus, Ullevål

og

Immunologisk institutt

Universitetet i Oslo

\section{ELISABETH GULOWSEN CELIUS}

Oslo universitetssykehus, Ullevål

\section{BAKGRUNN.}

Dagens førstelinjebehandling av multippel sklerose har moderat effekt og gir hyppig plagsomme bivirkninger, men en rekke nye legemidler er under utvikling. Målsetningen med denne artikkelen er å gi en oversikt over hvilke muligheter og utfordringer som er knyttet til disse midlene.

\section{MATERIALE OG METODE.}

Artikkelen bygger på et ikke-systematisk litteratursøk i PubMed, kongressammendrag og forfatternes egen forskning.

\section{RESULTATER.}

Monoklonale antistoffer som natalizumab, alemtuzumab, rituksimab og daclizumab og perorale medikamenter som kladribin og fingolimod er målstyrt mot molekyler eller celler som er viktige i den immunologiske sykdomsprosessen ved multippel sklerose.

Preparatene ser ut til å ha betydelig effekt på sykdomsutviklingen ved attakkpreget multippel sklerose, men kan være assosiert med alvorlige bivirkninger. Natalizumab er allerede registrert for bruk som annenlinjebehandling ved attakkpreget multippel sklerose og som førstelinjebehandling i svært alvorlige tilfeller. Kladribin og fingolimod kan komme på det norske markedet i løpet av 2011.

\section{FORTOLKNING.}

Behandlingen av attakkpreget multippel sklerose er i endring. Indikasjonsstillingen for nye legemidler er ennå ikke klarlagt og vil blant annet være avhengig av forekomsten av sjeldne, men alvorlige bivirkninger som ikke nødvendigvis er klarlagt gjennom studier forut for registrering. 
Multippel sklerose (MS) er en hyppig årsak til nevrologisk invaliditet hos unge voksne i den vestlige verden. Sykdommen er relativt hyppig i Norge, der vi antar at om lag 7 ooo personer er rammet (1). Hos de fleste starter sykdommen med mer eller mindre forbigående episoder med nevrologisk dysfunksjon (attakk) forårsaket av betennelse i sentralnervesystemet. Det kalles da attakkpreget (relapsing-remitting) multippel sklerose. Mange vil i løpet av 15-20 år utvikle såkalt sekundær progressiv multippel sklerose med jevnt progredierende funksjonstap. Dessverre mangler gode indikatorer for prognosen hos den enkelte pasient (므). Hos om lag 10-15\% er sykdommen progredierende fra starten (primær progressiv). Denne sykdomsformen har man foreløpig ikke funnet effektiv terapi for.

Immunmodulerende behandling av attakkpreget multippel sklerose med betainterferon og glatirameracetat ble tatt i bruk i 1990-årene og er vist å redusere antall nye attakk med om lag 30\%. Effekten på utvikling av permanent invaliditet er mer usikker og sannsynligvis mindre (3). Glatirameracetat og betainterferon administreres gjennom daglig til ukentlig selvinjeksjon og gir hyppig plagsomme bivirkninger i form av innstikksreaksjoner og/eller influensaliknende symptomer. Cytostatikumet mitoksantron er sannsynligvis mer effektivt, men bruken er begrenset av kardiotoksisitet og risiko for terapiindusert leukemi (4). Det er derfor stort behov for medikamenter med bedre effekt, bivirkningsprofil og administrasjonsform. Hensikten med denne artikkelen er å presentere nye behandlingsmetoder som nylig er tatt i bruk eller har kommet langt i utviklingsprosessen.

\section{Materiale og metode}

Vi har identifisert artikler gjennom ikke-systematiske søk i Pubmed og vår egen forskning. Omfattende studier av behandlingseffekt og bivirkninger samt ferske oversiktsartikler skrevet av ledende forskere er prioritert ved utarbeiding av referanselisten.

\section{Sykdoms- og virkningsmekanismer}

Ved multippel sklerose fører infiltrasjon av lymfocytter til inflammasjon i sentralnervesystemet, med demyelinisering og nevrodegenerasjon til følge. Immunologisk forskning, først og fremst i dyremodellen eksperimentell autoimmun encefalomyelitt, har identifisert en rekke nye målmolekyler for behandling (5). I tillegg har farmakologiske fremskritt, spesielt utvikling av monoklonale antistoffer, gitt mulighet for målstyrt behandling rettet mot molekyler og celler som er instrumentelle i sykdomsprosessen. Figur 1 viser hvordan nye behandlingsalternativer virker inn på immunpatogenesen ved multippel sklerose. To av disse (kladribin og fingolimod) kan være på markedet i 2011. 


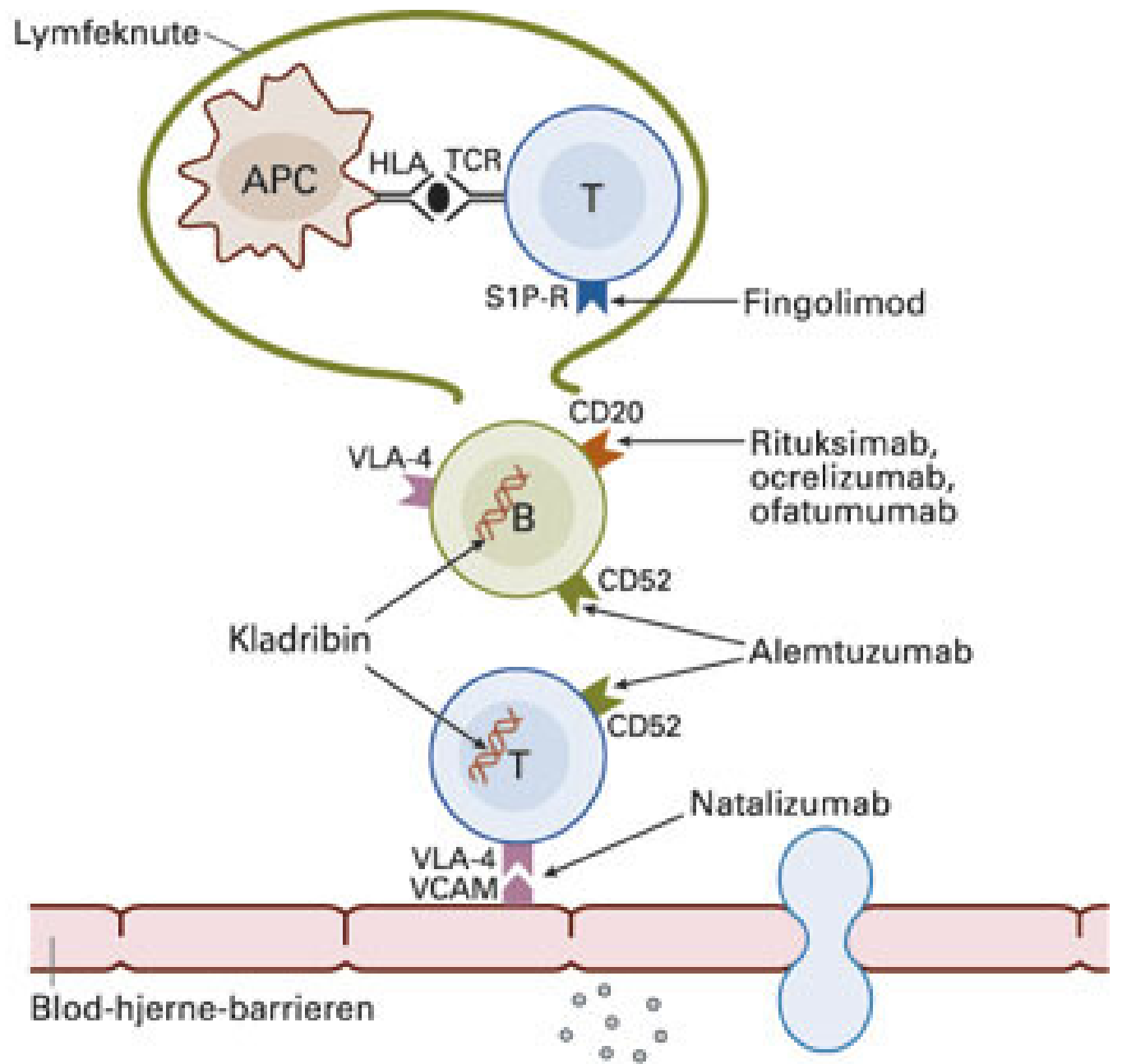

Kjemokiner, proteinaser $<-0$

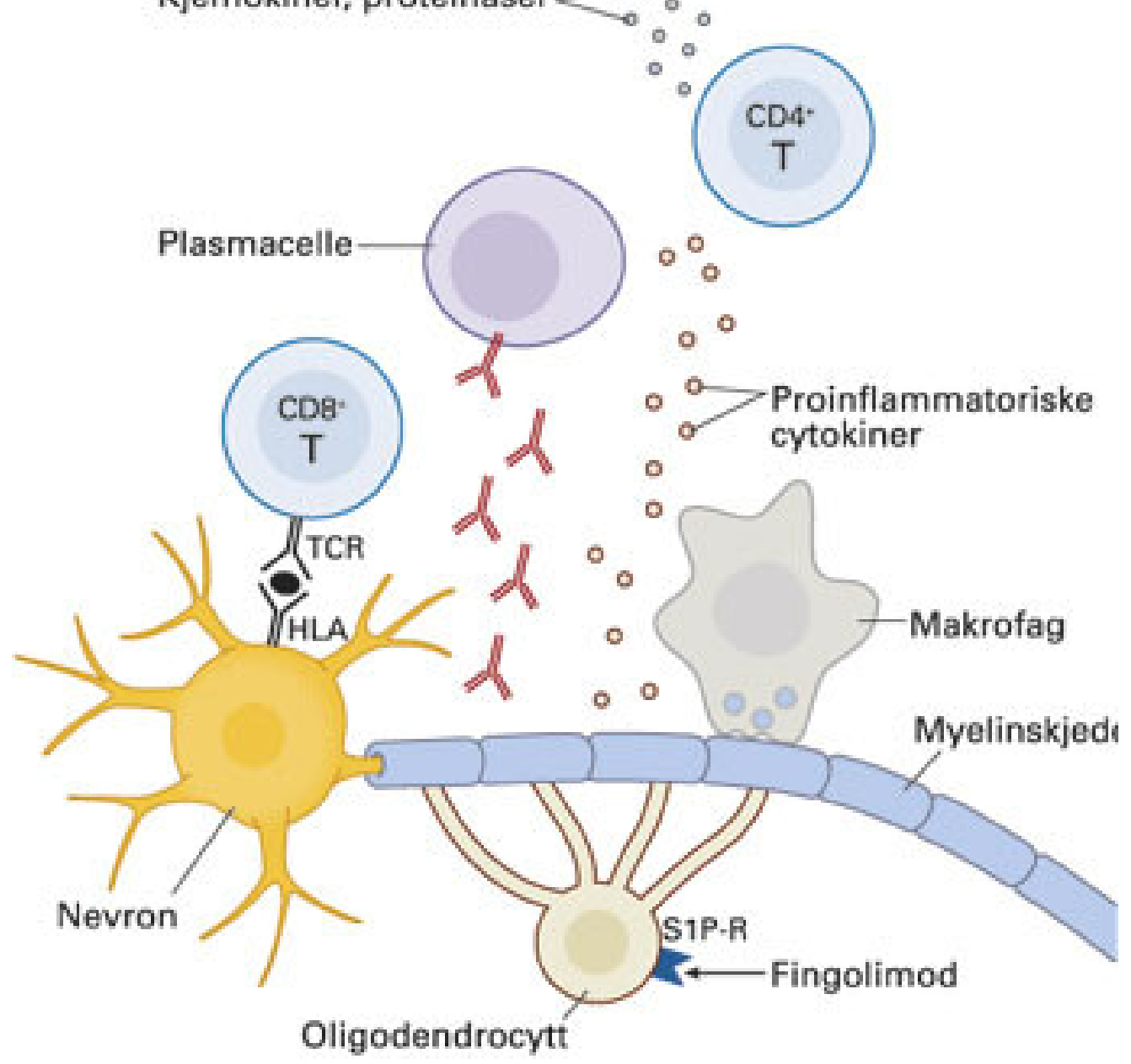


Figur 1 Oversikt over angrepspunkter for et utvalg nye medikamenter mot multippel sklerose. Medikamentene supprimerer på ulike måter det adaptive immunsystemet og hemmer infiltrasjon av lymfocytter i sentralnervesystemet. T-celler som aktiveres i lymfeknuter, uttrykker spingosin-1-fosfatreseptor (S1P-R) og VLA-4 (very late antigen 4). Disse molekylene er nødvendig for at T-cellene skal forlate lymfeknuten og penetrere blodhjerne-barrieren, og er mål for henholdsvis fingolimod og natalizumab. Rituksimab, ocrelizumab og ofatumumab dreper B-celler som uttrykker CD2O, mens alemtuzumab dreper både B-celler og T-celler som uttrykker CD56. Kladribin virker cytotoksisk på lymfocytter og monocytter (ikke vist)

Det mest relevante målet for effekt av immunmodulerende terapi ved multippel sklerose er effekten på utviklingen av irreversibel invaliditet. Utviklingen av invaliditet skjer over mange år. Ønsket om at nye medikamenter raskt skal komme i vanlig klinisk bruk, har ført til at kliniske studier sjelden varer lenger enn to år. Studier etter at det er gitt markedsføringstillatelse for medikamentet (post marketing-studier) gir usikker informasjon, fordi mange pasienter avslutter eller bytter behandling etter studieperioden. Sikre opplysninger om langtidseffekter mangler derfor oftest.

Behandlingseffekt måles også som reduksjon i antall kliniske attakker sammenliknet med placebo eller etablert behandling. Inflammatorisk aktivitet kan også måles i form av antall kontrastladende og nytilkomne lesjoner ved MR, men sammenhengen med sykdomsutviklingen er fortsatt uavklart. Dette blir derfor tillagt mindre vekt i denne artikkelen. Ettersom det finnes etablert behandling med moderat dokumentert effekt, innebærer placebokontrollerte studier vanskelige etiske og vitenskapelige spørsmål. I dag gjennomføres slike studier fortrinnsvis i land der mange pasienter ikke har råd til etablert behandling.

\section{Monoklonale antistoffer}

Monoklonale antistoffer er opprinnelig fremstilt i mus eller andre dyr. De monoklonale antistoffene som er aktuelle ved multippel sklerose, har en variabel del som binder seg spesifikt til viktige molekyler i sykdomsprosessen. For å unngå immunreaksjoner mot antistoffet er konstantregionen, eventuelt også deler av variabelregionen, erstattet med tilsvarende del av antistoffmolekylet fra et humant immunglobulin. Antistoffene kalles da henholdsvis kimeriske eller humaniserte. Enkelte pasienter vil likevel utvikle antistoffer mot de monoklonale antistoffene. Dette kan forårsake hypersensitivitetsreaksjoner og bortfall av behandlingseffekten. Det er utviklet immunologiske metoder for å påvise antistoffer mot disse medikamentene i serum, og slike analyser for natalizumab er tilgjengelig ved Haukeland universitetssykehus. Monoklonale antistoffer administreres som infusjon en gang i måneden eller sjeldnere.

\section{NATALIZUMAB}

Natalizumab binder seg til integrinet $\alpha_{4} \beta_{1}$ (very late antigen 4, VLA4), som uttrykkes på aktiverte T- og B-celler, og er nødvendig for at disse skal kunne krysse blod-hjernebarrieren. Preparatet ble tatt i bruk ved multippel sklerose i 2005, etter at en fase 3-studie hadde vist $68 \%$ reduksjon i antall attakker og $42 \%$ reduksjon i utvikling av permanent invaliditet sammenliknet med placebo (므). Liknende resultater ble vist i en annen studie av natalizumab som tilleggsbehandling hos pasienter som hadde sykdomsaktivitet til tross for behandling med betainterferon (7.).

Natalizumab er både det første monoklonale antistoffet som er godkjent ved multippel sklerose og det første preparatet som blokkerer et nøkkelmolekyl i sykdomsprosessen. Selv om man i lang tid hadde gått ut fra at migrasjon av lymfocytter over blod-hjerne-barrieren var en vesentlig del av sykdomsprosessen ved multippel sklerose, var det først behandlingseffekten med natalizumab som viste dette. 
Det har dessverre ikke vært utført sammenliknende studier, men ut fra placebokontrollerte studier er det liten tvil om at natalizumab er mer effektivt enn betainterferon og glatirameracetat ved attakkpreget multippel sklerose. Subjektive bivirkninger forekommer sjelden. Hovedproblemet har vært utvikling av progressiv multifokal leukoencefalopati (PML), som er en opportunistisk infeksjon i hjernen forårsaket av JC-virus og som vanligvis ses ved aids og andre former for cellulær immunsvikt. De fleste mennesker er bærere av JCvirus, men viruset forårsaker ikke sykdom dersom T-cellefunksjonen er intakt. Per mai 2010 hadde 47 av totalt 70 ooo behandlede pasienter fått progressiv multifokal leukoencefalopati, hvorav 11 var døde (Glenn Gundersen, Biogen Idec, personlig meddelelse). Siden mange pasienter hadde fått preparatet i kort tid, tilsvarer dette en hyppighet på om lag 1 per 1 ooo behandlingsår. Dette har ført til at det europeiske legemiddelverket (EMA) har godkjent natalizumab til bruk ved alvorlig attakkpreget multippel sklerose som ikke responderer på førstelinjebehandling, og som førstehåndsbehandling kun ved svært alvorlig attakkpreget multippel sklerose. 330 pasienter med multippel sklerose hadde ved utgangen av 2009 fått natalizumab i Norge, og det var ikke registrert tilfeller av progressiv multifokal leukoencefalopati (Glenn Gundersen, Biogen Idec, personlig meddelelse).

Nøytraliserende antistoffer mot natalizumab forekommer hos færre enn $6 \%$ av alle som behandles med natalizumab, og opptrer oftest i løpet av første behandlingsår. Analyse av nøytraliserende antistoffer bør derfor utføres seks og 12 måneder etter oppstart av behandling samt ved allergiske reaksjoner og mulig terapisvikt. Analysen kan utføres ved Haukeland universitetssykehus.

\section{ALEMTUZUMAB}

Alemtuzumab er et cytotoksisk antistoff rettet mot overflatemolekylet CD52 som er uttrykt på alle T- og B-celler. Behandlingen fører til uttalt og langvarig lymfocytopeni og har i flere år vært brukt mot spesielle former for leukemi. Antall B-celler og monocytter normaliseres etter tre måneder, mens T-hjelpeceller er supprimert i 6o måneder. I tillegg endres sammensetningen av lymfocyttene, med en økning av regulatoriske celler som kan bidra til den kliniske effekten gjennom å supprimere autoreaktive T-celler ( $\underline{8})$. En fase 2-studie over tre år hos pasienter med attakkpreget sykdom i tidlig fase viste en signifikant og betydelig bedre effekt både på betennelsesaktivitet målt ved MR og på attakkhyppighet enn betainterferon (årlig attakkrate o,10 ved alemtuzumab versus 0,36 ved placebo; $\mathrm{p}<0,001$ ) $(\underline{8})$.

Viktigere var at pasientene som fikk alemtuzumab, i gjennomsnitt hadde noe bedre nevrologisk funksjon etter tre år enn ved studiestart, mens de som fikk betainterferon, fortsatte å bli dårligere (ㅁ) . Selv om noen pasienter også rapporterer bedret funksjon etter oppstart av natalizumab, var dette et oppsiktsvekkende positivt resultat, fordi man tradisjonelt har antatt at etablert funksjonstap ikke kan gjenvinnes. Ettersom bedringen tilkom de første måneder etter behandlingsstart, er det sannsynlig at den hovedsaklig skyldes eliminering av betennelse som hadde supprimert nevrologisk funksjon. MR viste imidlertid en liten $ø$ kning av hjernens volum gjennom studieperioden, hvilket muligens kan tyde på at reparasjonsprosesser også fant sted.

Som ved annen kraftig immunsuppresjon frykter man at alemtuzumab vil utløse infeksjoner. Selv om det har vært observert økt hyppighet av infeksjoner, har disse stort sett vært milde, med unntak av ett tilfelle av listeriameningitt ( $\underline{8})$. Utvikling av andre autoimmune sykdommer, i første rekke tyreoiditt, har hittil vært den hyppigste alvorlige bivirkningen av alemtuzumab ved multippel sklerose (ㅇ). Dette har rammet 20-30\% av pasientene og har hos en del krevd behandling (ㅇ). I tillegg har snaut 3\% utviklet idiopatisk trombocytopenisk purpura, og én pasient døde av hjerneblødning som følge av dette ( $\underline{8})$. Denne bivirkningen var uventet ut fra preparatets virkningsmekanisme. Trombocytter og blødningstendens (hematuri, hudblødninger, misfarget avføring) ble derfor ikke overvåket, og man håper og tror at bedret overvåking vil føre til at alvorlige blødninger kan unngås. En fase 3-studie forventes avsluttet i 2011. 
Rituksimab er et cytotoksisk antistoff mot B-cellemarkøren CD2o og har vært i bruk i flere år mot andre autoimmune sykdommer og leukemi. CD2o er uttrykt på de fleste typer Bceller, og rituksimab fører til uttalt deplesjon av antall B-celler i blodet. En fase 2-studie av 104 pasienter viste 91\% reduksjon i sykdomsaktiviteten målt ved MR sammenliknet med placebo etter 24 måneder (9.). Attakkhyppigheten ble halvert, men reduksjonen var statistisk signifikant bare ved 12 måneder. CD2o er ikke uttrykt på antistoffproduserende plasmaceller, og effekten av rituksimab viser at B-cellene spiller en viktig rolle ved

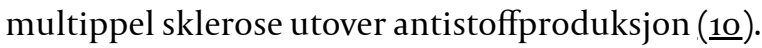

En fase 3-studie med 439 pasienter med primær progressiv multippel sklerose viste ingen overbevisende effekt av rituksimab (1ㅡ). Dette er i tråd med erfaringen med alemtuzumab og annen immunmodulerende og antiinflammatorisk behandling, som viser at systemisk antiinflammatorisk behandling kun er klinisk nyttig ved attakkpreget sykdom (모). Dette skyldes sannsynligvis at nevrodegenerasjonen ved progressiv sykdom skjer uavhengig av at lymfocytter fra blodet trenger inn i sentralnervesystemet.

Et problem med rituksimab er danning av såkalt antikimeriske antistoffer, som er blitt observert hos $20 \%$ av pasientene, og som kan nøytralisere effekten av preparatet (9.). Det er også registrert flere tilfeller av progressiv multifokal leukoencefalopati under bruk av rituksimab ved andre immunologiske og neoplastiske sykdommer, men årsakssammenhengen er ikke avklart.

ANDRE ANTISTOFFER

To humaniserte anti-CD2o-antistoffer (ocrelizumab og ofatumumab) er under fase-2utprøvning. Daclizumab er rettet mot interleukin-2-reseptoren CD25, som uttrykkes av aktiverte T-celler. Preparatet hemmer proliferasjon av T-cellene og øker antall

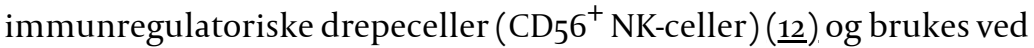
transplantatrejeksjoner. En fase 2-studie av pasienter med attakkpreget multippel sklerose med sykdomsaktivitet under behandling med betainterferon viste god effekt på sykdomsaktivitet målt ved MR, mens reduksjon av kliniske attakk ikke var statistisk signifikant (12). En fase 2-studie av daclizumab som monoterapi er i gang.

\section{Perorale medikamenter}

Kladribin og fingolimod (FTY720) har vært igjennom store fase 3-studier. De er søkt godkjent i Europa, og fingolimod er nylig blitt godkjent i USA.

Kladribin er en syntetisk purinanalog som inkorporeres i DNA og induserer apoptose av lymfocytter og monocytter. Preparatet er registrert mot hårcelleleukemi. En placebokontrollert fase 3-studie der 1362 pasienter med attakkpreget multippel sklerose ble randomisert til kladribin (3,5 mg eller 5,25 mg per kg kroppsvekt) eller placebo i 96 uker, viste betydelig reduksjon av attakkhyppighet (årlig attakkrate ved 3,5 mg og 5,25 mg kladribin var henholdsvis o,14 og o,15 vs. o,33 ved placebo; $\mathrm{p}<0,001$ ) (13). Sammenliknet med placebo ga kladribin om lag en tredels reduksjon i risikoen for å utvikle permanent invaliditet, dvs. invaliditet som vedvarte mer enn tre måneder. Som forventet forekom lymfopeni og leukopeni hyppig, men infeksjonstendensen så ikke ut til å øke. Tre pasienter som fikk kladribin utviklet kreft (ovariecancer, pancreascancer og malignt melanom) og én pasient fikk cervixdysplasi, mens ingen i placebogruppen fikk påvist malignitet (133).

Fingolimod modulerer sfingosin-1-fosfat (S1P)-reseptor 1, som regulerer migrasjon av lymfocytter fra lymfeknuter til blod. Hovedeffekten er at T-cellene hemmes i å forlate lymfeknutene, men det er muligens også en direkte påvirkning av nevroner, oligodendrocytter og gliaceller (14.). En fase 3-studie av 1272 pasienter fulgt opp i to år viste at $0,5 \mathrm{mg}$ og 1,25 mg fingolimod reduserte attakkfrekvensen med henholdsvis 54\% og 6o\% sammenliknet med placebo (15). Utviklingen av invaliditet ble også redusert. En studie av 1 292 pasienter over ett år viste at effekten på attakkfrekvensen var betydelig mer uttalt ved 
fingolimod enn ved betainterferon: Årlig attakkrate ved o,5 mg og 1,25 mg fingolimod var henholdsvis 0,20 og o,16, mot o,33 ved betainterferon, $\mathrm{p}<0,001)$, men utviklingen av invaliditet var ikke signifikant forskjellig (16 $)$. Det er blitt registrert tilfeller av kreft (basalcellekarsinom, plateepitelkarsinom, melanom og brystkreft) og cerebral sirkulasjonsforstyrrelse, og to pasienter har dødd av infeksjoner (varicella zoster og herpes zoster). Det er foreløpig usikkert i hvilken grad risikoen er økt og om dette eventuelt er knyttet til høyere dose enn det som vil være aktuelt i klinisk bruk. S1P-reseptorer er også uttrykt i hjertet. Bradykardi og atrioventrilulært blokk forekommer derfor ved oppstart av behandlingen, og medikamentet kan også utløse både hypotensjon og hypertensjon (15,16).

Flere andre perorale medikamenter har vist lovende resultater i fase 2-studier. Både teriflunomid, laquinimod og fumarat (BG12) er vist å hemme inflammatorisk sykdomsaktivitet ved attakkpreget sykdom målt ved MR (므). Selv om effekten på attakkfrekvensen ikke har vært signifikant, undersøkes de nå i fase 3-studier. Preparatene virker immunmodulerende, men virkningsmekanismen er mindre kartlagt og muligens mindre spesifikk enn for de monoklonale antistoffene. Teriflunomid hemmer aktivering og proliferasjon av T- og B-celler gjennom hemming av pyrimidinsyntesen, mens laquinimod og fumarat blant annet påvirker T-cellenes cytokinprofil og ekspresjon av adhesjonsmolekyler $(\underline{16}, \underline{18})$.

\section{Andre behandlingsalternativer}

En rekke andre behandlingsformer har gitt lovende resultater i dyremodeller og $\mathrm{i}$ pilotstudier og kan være aktuelle for videre utprøvning. Dette gjelder bl.a. derivater av vitamin $\mathrm{D}$, testosteron, prolaktin og estradiol, som muligens kan påvirke risikoen for multippel sklerose eller sykdomsforløpet $(\underline{19}, \underline{20})$. Renin-angiotensin-systemet ser ut til å påvirke immunsystemet, og hemming av angiotensin II-konverterende enzym med enalapril er nylig vist å hemme utviklingen av eksperimentell autoimmun encefalomyelitt (21).

Mange preparater har vist effekt ved eksperimentell autoimmun encefalomyelitt, men ikke ved multippel sklerose. Et eksempel på dette er såkalt antigenspesifikk behandling gjennom T-cellevaksinering. Denne behandlingen bygger på antakelsen om at multippel sklerose, i likhet med eksperimentell autoimmun encefalomyelitt, medieres av en immunrespons mot enkelte myelinproteiner og at induksjon av immunologisk toleranse kan stanse sykdomsutviklingen. Selektiv hemming av den skadelige immunresponsen kunne tenkes å kurere sykdommen uten å øke risikoen for infeksjoner eller kreft. Til tross for suksess i dyremodeller og i pilotstudier har antigenspesifikk behandling ikke vist

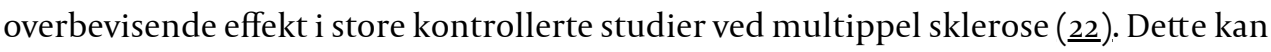
skyldes at modellene ikke reflekterer hele sykdomsmekanismen.

Forsøk med reparasjon av ødelagt nervevev med mesenkymale stamceller ved multippel sklerose har kommet kort. Det er imidlertid blitt utført kliniske studier av hematopoetiske stamceller som tillegg til høydosert cytostatikabehandling. Denne behandlingsformen tar ikke primært sikte på å erstatte ødelagt nervevev, men å fjerne autoreaktive lymfocytter og dempe betennelsesreaksjonen. Autologe stamceller muliggjør bruk av aggressiv cytostatikabehandling og kan i seg selv virke antiinflammatorisk. Det er nylig publisert oppsiktsvekkende resultater hos ni svenske pasienter med særlig aggressiv attakkpreget sykdom (23). Flere pasienter gjenvant nevrologisk funksjon i betydelig grad og beholdt denne gjennom flere år uten å få nye attakker. Studien var imidlertid liten og åpen og tillater ikke sikre konklusjoner, verken om effekt eller risiko. Behandlingen gir forbigående beinmargsaplasi og er forbundet med mortalitet. Den er foreløpig ikke tatt i bruk ved multippel sklerose i Norge. Forhåpentligvis vil en pågående multisenterstudie bidra til å avklare hvilken plass behandlingen bør ha (24).

\section{Utfordringer fremover}


Selv om det finnes få sammenliknende studier, tror vi at medikamenter som natalizumab, alemtuzumab, kladribin og fingolimod er mer effektive enn dagens førstelinjebehandling ved attakkpreget multippel sklerose. Alle disse medikamentene ser ut til å ha en mer uttalt effekt på hyppigheten av attakker enn betainterferon og glatirameracetat. Det er gode holdepunkter for at flere av preparatene også reduserer utviklingen av permanent invaliditet, noe som er klinisk viktigere. Fordi studienes varighet er relativt kort i forhold til det kroniske forløpet av sykdommen, kan vi imidlertid foreløpig ikke konkludere sikkert vedrørende den kliniske effekten på lang sikt. Dersom resultatene som er observert i studieperiodene vedvarer, vil preparatene bedre pasientenes prognose betydelig.

Mye tyder imidlertid på at effekten vil være størst tidlig i sykdomsforløpet, mens inflammasjonen er mest aktiv. I tråd med dette påvirket ikke alemtuzumab utvikling av invaliditet hos pasienter med sekundær progressiv sykdom selv om antall attakker ble redusert ( $\underline{8})$, og studier av sykdommens naturlige forløp har vist at betydningen av attakker for utvikling av invaliditet sannsynligvis avtar så tidlig som etter fem år (25). Pasienter som har hatt sykdommen over lang tid, eller som har progressiv sykdom, vil derfor sannsynligvis ha liten nytte av de nye medikamentene som her er omtalt. Medikamenter

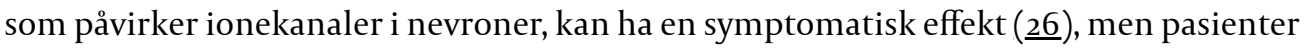
med progressiv multippel sklerose vil neppe få vesentlig bedre behandlingsmuligheter $i$ overskuelig fremtid. Mer kunnskap om sykdomsmekanismen ved denne sykdomsformen er derfor nødvendig.

De mest effektive nye behandlingsalternativene ved multippel sklerose innebærer betydelig modulering og suppresjon av det adaptive immunforsvaret. Foreløpig kjenner vi ikke til de fulle konsekvensene dette kan ha for risikoen for infeksjoner og utvikling av kreft. Erfaringene med natalizumab er tankevekkende, fordi man først ble klar over risikoen for progressiv multifokal leukoencefalopati etter at preparatet var introdusert på det amerikanske markedet. Årsaken er at denne bivirkningen er så sjelden at den ikke ble fanget opp i fase 3-studiene. Dette viser betydningen av nitid overvåking og registrering av bivirkninger etter at medikamentene er registrert (27.). I Norge er det etablert et nasjonalt register for multippel sklerose, som også registrerer bivirkninger ved behandling, men en overnasjonal monitorering vil være nødvendig for å avdekke sjeldne bivirkninger.

Erfaringene med progressiv multifokal leukoencefalopati illustrerer også at pasienten og deres lege ikke alltid kan være klar over den hele og fulle risiko knyttet til et nytt preparat. Valg av behandling vil således bli en avveining av nytte og risiko der flere viktige premisser er delvis ukjent, ikke minst den enkelte pasients prognose uten behandling. Hensynet til pasientens autonomi tilsier at legen skal gi korrekt og åpen informasjon om sykdommens prognose og medikamentenes effekt og deres potensielle bivirkninger.

\section{Oppgitte interessekonflikter:}

Trygve Holmøy har mottatt forskningsstøtte fra Sanofi-Aventis, Bayer, Biogen Idec og Merck-Serono, foredragshonorar fra Sanofi-Aventis, Biogen Idec og Novartis og reisestøtte fra Sanofi-Aventis, Biogen Idec og Merck-Serono. Elisabeth Gulowsen Celius har mottatt reisestøtte og honorar for foredrag/konsulenttjenester fra Sanofi-Aventis, Biogen Idec, Bayer-Schering, Biogen Idec og Novartis.

\section{Tabell}

Hovedbudskap 


\begin{tabular}{|l|}
\hline Hovedbudskap \\
\hline Betainterferon og glatirameracetat er i dag vanlig førstelinjebehandling for attakkpreget \\
multippel sklerose, men effekten på sykdomsutviklingen er begrenset og de gir ofte \\
plagsomme bivirkninger \\
En rekke monoklonale antistoffer og to perorale medikamenter ser ut til å ha bedre effekt. \\
Natalizumab er allerede i vanlig klinisk bruk, mens fingolimod og kladribin er søkt registrert \\
- De nye medikamentene tolereres oftest godt, men kan ha sjeldne og alvorlige bivirkninger \\
som ikke er fanget opp i kliniske studier
\end{tabular}

\section{LITTERATUR}

1. Smestad C, Sandvik L, Holmøy T et al. Marked differences in prevalence of multiple sclerosis between ethnic groups in Oslo, Norway. J Neurol 2008; 255: 49-55. [PubMed] [CrossRef]

2. Smestad C, Sandvik L, Landrø NI et al. Cognitive impairment after three decades of multiple sclerosis. Eur J Neurol 2010; 17: 499-505. [PubMed] [CrossRef]

3. Katrych O, Simone TM, Azad S et al. Disease-modifying agents in the treatment of multiple sclerosis: a review of long-term outcomes. CNS Neurol Disord Drug Targets 2009; 8: 512-9. [PubMed]

4. Marriott JJ, Miyasaki JM, Gronseth G et al. Evidence Report: The efficacy and safety of mitoxantrone (Novantrone) in the treatment of multiple sclerosis: Report of the Therapeutics and Technology Assessment Subcommittee of the American Academy of Neurology. Neurology 2010; 74: 1463-70. [PubMed] [CrossRef]

5. Holmøy T, Harbo H, Vartdal F et al. Genetic and molecular approaches to the immunopathogenesis of multiple sclerosis: an update. Curr Mol Med 2009; 9: 591-611. [PubMed] [CrossRef]

6. Polman $\mathrm{CH}$, O'Connor PW, Havrdova E et al. A randomized, placebo-controlled trial of natalizumab for relapsing multiple sclerosis. N Engl J Med 2006; 354: 899-910. [CrossRef]

7. Rudick RA, Stuart WH, Calabresi PA et al. Natalizumab plus interferon beta-1a for relapsing multiple sclerosis. N Engl J Med 2006; 354: 911-23. [CrossRef]

8. Jones JL, Coles AJ. Spotlight on alemtuzumab. Int MS J 2009; 16: 77-81. [PubMed]

9. Hauser SL, Waubant E, Arnold DL et al. B-cell depletion with rituximab in relapsing-remitting multiple sclerosis. N Engl J Med 2008; 358: 676-88. [PubMed] [CrossRef]

10. Cross AH, Stark JL, Lauber J et al. Rituximab reduces B cells and T cells in cerebrospinal fluid of multiple sclerosis patients. J Neuroimmunol 2006; 180: 63-70. [PubMed] [CrossRef]

11. Hawker K, O'Connor P, Freedman MS et al. Rituximab in patients with primary progressive multiple sclerosis: results of a randomized double-blind placebo-controlled multicenter trial. Ann Neurol 2009; 66: 460-71. [PubMed] [CrossRef]

12. Schippling DS, Martin R. Spotlight on anti-CD25: daclizumab in MS. Int MS J 2008; 15: 94-8. [PubMed]

13. Giovannoni G, Comi G, Cook $S$ et al. A placebo-controlled trial of oral cladribine for relapsing multiple sclerosis. N Engl J Med 2010;362: 416-26. [PubMed] [CrossRef]

14. Brinkmann V. FTY720 (fingolimod) in multiple sclerosis: therapeutic effects in the immune and the central nervous system. Br J Pharmacol 2009; 158: 1173-82. [PubMed] [CrossRef]

15. Kappos L, Antel J, Comi G et al. Oral fingolimod (FTY720) for relapsing multiple sclerosis. N Engl J Med 2006; 355: 1124-40. [PubMed] [CrossRef]

16. Cohen JA, Barkhof F, Comi G et al. Oral fingolimod or intramuscular interferon for relapsing multiple sclerosis. N Engl J Med 2010;362: 402-15. [PubMed] [CrossRef]

17. Gasperini C, Ruggieri S. New oral drugs for multiple sclerosis. Neurol Sci 2009;30 (suppl 2): 17983. [PubMed] [CrossRef]

18. Warnke C, Meyer Zu Hörste G, Hartung HP et al. Review of teriflunomide and its potential in the treatment of multiple sclerosis. Neuropsychiatr Dis Treat 2009; 5:333-40.

19. Myhr KM. Vitamin D treatment in multiple sclerosis. J Neurol Sci 2009; 206: 104-8. [CrossRef] 
20. Gold SM, Voskuhl RR. Estrogen and testosterone therapies in multiple sclerosis. Prog Brain Res 2009; 175: 239-51. [PubMed] [CrossRef]

21. Stegbauer J, Lee DH, Seubert $S$ et al. Role of the renin-angiotensin system in autoimmune inflammation of the central nervous system. Proc Natl Acad Sci U S A 2009; 106: 14942-7. [PubMed] [CrossRef]

22. Giacomini PS, Bar-Or A. Antigen-specific therapies in multiple sclerosis. Expert Opin Emerg Drugs 2009; 14: 551-6o. [PubMed] [CrossRef]

23. Fagius J, Lundgren J, Oberg G. Early highly aggressive MS successfully treated by hematopoietic stem cell transplantation. Mult Scler 2009; 15: 229-37. [PubMed] [CrossRef]

24. Farge D, Labopin M, Tyndall A et al. Autologous hematopoietic stem cell transplantation for autoimmune diseases: an observational study on 12 years' experience from the European Group for Blood and Marrow Transplantation Working Party on Autoimmune Diseases. Haematologica 2010; 95: 284-92. [PubMed] [CrossRef]

25. Tremlett H, Yousefi M, Devonshire V et al. Impact of multiple sclerosis relapses on progression diminishes with time. Neurology 2009; 73:1616-23. [PubMed] [CrossRef]

26. Goodman AD, Brown TR, Krupp LB et al. Sustained-release oral fampridine in multiple sclerosis: a randomised, double-blind, controlled trial. Lancet 2009; 373: 732-8. [PubMed] [CrossRef]

27. Clifford DB. DeLucaA, Simpson DM. Natalizumab-associated progressive multifocal leukoecephalopathy in patients with multiple sclerosis: lessons from 28 cases. Lancet Neurol 2010; 9: 438-46. [PubMed] [CrossRef]

Publisert: 6. mai 2011. Tidsskr Nor Legeforen. DOI: 10.4045/tidsskr.10.0077

Mottatt 21.1. 2010, første revisjon innsendt 12.5. 2010, godkjent 16.9. 2010. Medisinsk redaktør Petter Gjersvik.

(C) Tidsskrift for Den norske legeforening 2023. Lastet ned fra tidsskriftet.no 26. april 2023. 